\title{
Direct Human Impacts on the Peatland Carbon Sink
}

\author{
Jukka Laine \\ Finnish Forest Research Institute, Parkano, Finland \\ Kari Minkkinen \\ Department of Forest Ecology, University of Helsinki, Helsinki, Finland \\ Carl Trettin \\ Center for Forested Wetlands Research, U.S. Forest Service, Cordesville, South Carolina, USA
}

Northern peatlands occupy over 3 million $\mathrm{km}^{2}$ globally and contain the largest carbon (C) pool (typically $>100 \mathrm{~kg} \mathrm{C} \mathrm{m}^{2}$ ) among terrestrial ecosystems. Agriculture, forestry, and peat harvesting are the principal human-induced activities that alter the peatland and hence the distribution and flux of carbon. As a prerequisite to those uses, the peatland is usually drained, which has long-term effects on the site hydrology and corresponding direct linkages to changes in C dynamics in the vegetation and soils. Soil organic matter decomposition is stimulated following drainage, typically reported as increased $\mathrm{CO}_{2}$ emissions and peat subsidence. The vegetation also changes following drainage, regardless of cropping or harvesting practices, and this change influences the net ecosystem $\mathrm{C}$ exchange rate. Peatland drainage tends to reduce $\mathrm{CH}_{4}$ emissions, as a result of a greater aerated surface soil volume. The net global effect of active management of northern peatlands has been to reduce the $\mathrm{C}$ pool, because agricultural use is dominant. There remain considerable uncertainties in estimating the $\mathrm{C}$ pools, fluxes, and responses to management in peatlands; the issues span inadequate inventories to sampling and measurements in complex settings.

\section{INTRODUCTION}

Peatlands are widely recognized as an important terrestrial carbon (C) pool. Their role in the global C cycle and the potential interactions with changing climatic conditions have been the subject of several recent reviews [Bridgham et al., 2006; Roulet, 2000; Trettin et al., 2006] and volumes [Strack, 2008]. The following is a synthesis of the effects

Carbon Cycling in Northern Peatlands

Geophysical Monograph Series 184

Copyright 2009 by the American Geophysical Union. 10.1029/2008GM000808 of land use change on the $\mathrm{C}$ cycle of northern peatlands intended to provide context for future work toward a better understanding of these ecologically important and sociologically valuable ecosystems.

\section{DIRECT HUMAN INFLUENCE: LAND USE CHANGE}

\subsection{Extent and Importance}

Agriculture, forestry, and peat extraction for fuel and horticultural use are the major causes of change in peatland 
Table 1. Area of Northern Peatlands Used in Agriculture and Forestry ${ }^{\mathrm{a}}$

\begin{tabular}{|c|c|c|c|c|c|}
\hline & \multirow{2}{*}{$\frac{\text { Total Peatland Area }}{\mathrm{km}^{2}}$} & \multicolumn{2}{|c|}{ Peatland Area Used for Agriculture } & \multicolumn{2}{|c|}{ Peatland Area Used for Forestry } \\
\hline & & $\mathrm{km}^{2}$ & $\%$ & $\mathrm{~km}^{2}$ & $\%$ \\
\hline Europe (without Russia) & 325,000 & 50,600 & 15 & 97,540 & 30 \\
\hline Russia & $1,390,000$ & 70,400 & 5 & 40,000 & 3 \\
\hline North America & $1,307,000^{b}$ & 231,000 & 18 & 4,250 & $<1$ \\
\hline China & 10,440 & 2,610 & 25 & 700 & 7 \\
\hline
\end{tabular}

aAdapted from Oleszczuk et al. [2008], Minkkinen et al. [2008], Bridgham et al. [2006], and Rydin and Jeglum [2006].

bIncludes $513 \times 10^{3} \mathrm{~km}^{2}$ permafrost peatlands.

condition. Conversion to agriculture has been the most extensive form of land use change, with approximately $13 \%$ of European peatlands currently used for this purpose, and somewhat more in North America and China (Table 1). In some European countries, more than half of the original peatland area is presently used for agriculture [Oleszczuk et al., 2008]. The majority of the agricultural use is for grazing as meadows and pastures, but lands are also cultivated for cereal crops. Agricultural use significantly alters the peatland $\mathrm{C}$ balance as a result of changes to vegetation, hydrology, and biogeochemical processes.

The utilization of peatlands for forestry is concentrated in Nordic and Baltic countries where approximately 30\% of peatland area has been drained for production forestry (Table 1). The use varies from extensive management regimes that may consist of harvesting and natural regeneration to intensive management prescriptions that may involve drainage, water management, and fertilization. Drainage is a common management prescription due to the constraints of saturated soil conditions on site productivity and operability; as a result, over 10 million ha of peatlands have been drained in the Nordic countries and Russia for silvicultural purposes [Paavilainen and Päivänen, 1995]. In Finland alone, more than 5 million ha is in production forestry. Production forestry in peatlands has important benefits to the local and national economy; in Finland, more than $20 \%$ of annual forest growth takes place in peatland forests [Päivänen, 2008].

The use of peat for domestic energy purposes by local communities has been common in many parts of the world for centuries. Large-scale use of peat in energy production started in the 20th century, and today, Finland, Ireland, Russia, Belarus, and Sweden account for almost $90 \%$ of the world's use [Holmgren et al., 2008], with an average annual consumption of 3.3 Mt [Paappanen et al., 2006]. Peat is also excavated and sold as a growing medium for horticultural use, but the volume used annually is approximately $50 \%$ that of fuel peat. Germany and Canada account for over half of horticultural peat extraction. The area used for peat produc- tion is very small in comparison to agricultural or forestry use: approximately 0.5 million ha. Although the amount of peat used for energy and horticultural use is relatively small, these represent important economic uses for communities and industries.

\subsection{Impacts on the Ecosystem}

Conversion of peatlands to other land uses typically involves alterations of the hydrology and plant community, both of which have consequences to the carbon cycle, carbon storage, and greenhouse gas emissions. The effects of land use conversion of peatlands are to change the rates of carbon sequestration, organic matter decomposition, and fluxes from the ecosystem. Assessing the impact on the $\mathrm{C}$ cycle necessarily involves the consideration of functional linkages among the vegetative community, soil biogeochemistry, the water balance, and the specific land use practices. The most evident effect of peatland drainage and utilization is the acceleration of oxidative processes in the surface peat.

The impacts of converting peatlands to agriculture on ecosystem properties and carbon storage were recently summarized by Oleszczuk et al. [2008]. For agricultural use, intensive drainage is used to achieve suitable hydrological conditions with sufficient aeration in the soil for the cultivated crops and pasture. The agricultural conversion process also involves the removal of the original peatland vegetation which is replaced with crop or pastoral species. The combination of altered hydrology and vegetation, and cultivation measures (e.g., tillage, fertilization), drastically change the carbon sequestration and sink functions of the land [KasimirKlemedtsson et al., 1997; Maljanen et al., 2004].

Similarly, drainage and water management systems are commonly associated with peatland forestry operations, but the intensity of drainage is much less than under agricultural systems. As a result of silvicultural drainage, the plant community changes to one dominated by tree stands and forest flora, but some of the original peatland species remain. As a result, the use of northern peatlands for forestry has smaller 
impacts on the ecosystem functions than those used for agriculture, but they tend to be more complex.

Utilization of a peatland for energy and horticultural products totally changes the structure and functions of the original ecosystem, as all the vegetation is removed at the onset of operations, and eventually, the majority of the peat is removed. During the production phase, $\mathrm{CH}_{4}$ and $\mathrm{N}_{2} \mathrm{O}$ emissions of the site are avoided, but the intensive drainage of these sites maintains high oxidative microbial activity in the peat layer resulting in large $\mathrm{CO}_{2}$ emissions [Alm et al., 2007; Holmgren et al., 2008].

\section{LAND USE IMPACTS ON THE CARBON SINK FUNCTIONS}

\subsection{Agriculture}

Under agricultural use, the peatland is drained and cultivated, resulting in increased aeration of the surface soil which enhances microbial activity and results in increased $\mathrm{CO}_{2}$ emissions. Despite the relatively large area of converted peatlands in North America, most of the available information comes from European studies, which show a wide range in emission estimates (Table 2). These estimates seem to depend more on the measurement methodology and agricultural system and less on the geographical location of the study sites [Oleszczuk et al., 2008]. High emissions have been reported from cereal crop cultivation using intensive drainage and annual tillage and also from fallow fields with bare soils [Maljanen et al., 2007]. Cultivated peat soils reflect the agricultural legacy after the use ends, as evidenced by rather high $\mathrm{C}$ losses from sites abandoned from cultivation [Maljanen et al., 2007].

Increased aeration in the surface soil generally enhances $\mathrm{CH}_{4}$ oxidation, resulting in decreased emissions; this effect often converts the soil into a $\mathrm{CH}_{4}$ sink [Kasimir-Klemedtsson et al., 1997; Flessa et al., 1998]. The activity of $\mathrm{CH}_{4}$-oxidizing bacteria may, however, be reduced by nitrogen fertilizer applications [Van den Pol-van Dasselaar et al., 1999; Reay and Nedwell, 2004]. The $\mathrm{CH}_{4}$ balance is highly dependent on the soil hydrology, and poorly drained soils may continue to emit methane during cultivation [Maljanen et al., 2003a]. In addition to increasing soil oxidation, agricultural use of

Table 2. Greenhouse Gas Emissions From European Peatlands Converted to Agriculture $^{\mathrm{a}}$

\begin{tabular}{lccc}
\hline & $\mathrm{CO}_{2}$ & $\mathrm{CH}_{4}$ & $\mathrm{~N}_{2} \mathrm{O}$ \\
\hline Emission range & $7000-22,000$ & $-5-4$ & $2-56$ \\
\hline
\end{tabular}

${ }^{a}$ Direct flux measurements modified from Oleszczuk et al. [2008]. Emissions are given in $\mathrm{kg}$ ha ${ }^{1} \mathrm{a}{ }^{1}$. peatlands reduces the net organic matter input to the soil, as a result of the crop utilization. The effect is to ensure that the peatland is a net source of $\mathrm{C}$ to the atmosphere, as a result of the increased soil oxidation and reduced input. In many European countries, greenhouse gas (GHG) emissions from agricultural peatlands dominate national emissions of GHGs from peat utilization in total [Oleszczuk et al., 2008].

\subsection{Forestry}

Impacts of silvicultural drainage on soil $\mathrm{CO}_{2}$ emissions are similar to agricultural soils whereby improved aeration increases the organic matter decomposition rate and the $\mathrm{CO}_{2}$ efflux from soil [e.g., von Arnold et al., 2005a, 2005b; Byrne and Farrel, 2005; Minkkinen et al., 2007; Silvola et al., 1996]. The increase in efflux is, however, smaller than in agricultural soils because resultant soil conditions are different under silviculture. Since peatland forestry is mainly based on the use of natural tree stands, tillage is not needed during stand development, which may take $50-100$ years. Forest fertilization may take place in some sites with unbalanced nutrient status, but it is far less common than in agricultural uses. Perennial plant cover remains, which means that $\mathrm{CO}_{2}$ fixation and organic $\mathrm{C}$ input to the soil continues despite the increased oxidation that is stimulated by the drainage. For these reasons, soils under forestry use are much less disturbed, and functionally, they resemble natural peatlands as opposed to intensively cultivated lands associated with agriculture.

The purpose of forestry drainage is to improve site conditions such that they are suitable for growing trees commercially and to improve the operability of the site. The net effect of peatland silviculture is that trees function as an effective $\mathrm{CO}_{2}$ sink [Laiho and Laine, 1997]. This sink includes the $\mathrm{C}$ bound in aboveground and belowground tree biomass and in the $\mathrm{C}$ deposited as litter on and in the soil [Laiho et al., 2003], where it decomposes at variable rates, depending on litter quality and conditions of the environment. Ground vegetation also contributes to the litter input to the soil; although the amount is highly variable, it is a significant proportion of the total (25-95\% [Laiho et al., 2003]). If this increase of biomass and litterfall is greater than the efflux from soil and litter decomposition, the drained peatland ecosystem remains a $\mathrm{C}$ sink. In the boreal zone, especially in the Nordic countries where peatland forestry is actively practiced, this is often the case, although differences in soil conditions, tree species, and climate, affect the ecosystem $\mathrm{C}$ balance. There are few eddy covariance measurement sites in drained peatland forests, but several of these (Sweden [Lindroth et al., 2007], Scotland [Hargreaves et al., 2003], Finland [Laurila et al., 2007]) support this view. Examples showing that the balance may in some cases be slightly [Lohila et al., 2007] 
or highly negative [Lindroth et al., 1998], however, also exist. National greenhouse gas assessments [e.g., Statistics Finland, 2009] indicate that generally, integrated over large areas, the tree stand $\mathrm{C}$ sink in forested peatlands exceeds the $\mathrm{C}$ efflux from peat soil.

The $\mathrm{CO}_{2}$ sink function of the peatland usually remains as long as the tree stand grows. After final fellings, primary production dramatically decreases, as the productive tree stand is harvested, and remaining ground vegetation suffers from the sudden change in microclimatic conditions. The fine roots of the harvested trees comprise a large stock of rather easily decomposable fresh organic matter, whereas the $\mathrm{C}$ pools bound in the stumps and coarse roots may persist for longer periods (e.g., decades) before they are decomposed [Laiho and Penttilä, 2006]. Most of the $C$ bound in the harvested trees is lost to the atmosphere, at first from the slash (needles, branches, etc.) left at the felling site, then from short-lived wood products like paper, but a small proportion $(<10 \%)$ remains in wood products for longer periods (tens of years) [Seppälä and Siekkinen, 1993; Minkkinen et al., 2002].

Following forestry drainage, $\mathrm{CH}_{4}$ emissions decrease [e.g., Nykänen et al., 1998; von Arnold et al., 2005a]. The decrease is caused by (1) increase in soil aeration and (2) decrease in easily decomposable organic matter input to waterlogged soil layers through aerenchymatous mire plants. These environmental changes in soil matrix simultaneously decrease microbial $\mathrm{CH}_{4}$ production and increase its oxidation. The changes are faster and more pronounced in the nutrient-rich sites, which become $\mathrm{CH}_{4}$ sinks, and act in a similar manner to mineral forest soils. However, even in the most nutrientpoor sites, $\mathrm{CH}_{4}$ emissions clearly decrease from the natural state, if the water table level is at all decreased.

An opposite impact can sometimes be created by the drainage ditches themselves. Ditches may sometimes act as $\mathrm{CH}_{4}$ hotspots, if they remain continuously wet [Roulet and Moore, 1995]. In some cases, $\mathrm{CH}_{4}$ emissions from ditches may totally compensate for the decreased emissions from the drained land between the ditches [Minkkinen and Laine, 2006]. It has not been established if this phenomenon is prevalent in drained forested peatlands, but clearly, a perspective that integrates the varying conditions across the entire peatland site merits consideration when attempting to derive unit-area estimates of emissions.

Carbon is also released from peatlands in the drainage water. The leaching of organic $\mathrm{C}$ increases during and immediately after construction of the drainage network, but because the groundwater flow through the peatland is decreased by ditches that trap the inflowing water, the long-term increase in organic C leaching is small (approximately 10\%, i.e., $1 \mathrm{~g}$ $\mathrm{C} \mathrm{m}^{2} \mathrm{a}^{1}$ [Sallantaus, 1994]), or it may even decrease [Lundin and Bergquist, 1990].
Based on available information from $\mathrm{C}$ studies in forested peatlands, we can state that the $\mathrm{C}$ sink function of a peatland is altered when it is drained for forestry. The direction of the change is, however, not unidirectional nor unambiguous. Some peatlands become $\mathrm{C}$ sources, some remain sinks, some may even increase their $\mathrm{C}$ sequestration rates. If the peat soil becomes a $\mathrm{C}$ source, ecosystem $\mathrm{C}$ balance will also, at some point in time, turn negative, when the previously bound tree $\mathrm{C}$ pool is released to the atmosphere through decomposition of the woody biomass.

\section{HOW TO REDUCE UNCERTAINTIES IN EMISSION ESTIMATES}

There are considerable uncertainties associated with estimating the $\mathrm{C}$ stocks and greenhouse gas emissions from managed and unmanaged peatlands alike. The issues involve sampling, measurement, and analyses, particularly when trying to assess change over time.

Measuring changes in the peat $\mathrm{C}$ stock requires accurate estimates of peat volume, bulk density, and C content. Unfortunately, most studies do not consider the total peat depth nor do they have a reference depth to support periodic remeasurements. Without a basal reference, it is very difficult to estimate changes in peat volume given the inevitable subsidence that is associated with most uses. Accurate bulk density measurements are also required, and seldom reported, in order to assess changes in peat $\mathrm{C}$ pools; for example, small variations in bulk density $\left(<0.01 \mathrm{~g} \mathrm{~cm}^{3}\right)$ can translate into large variations ( $>10 \mathrm{t}^{1}{ }^{1}$ ) in $\mathrm{C}$ pool estimates.

The surface of a peatland, whether natural or managed, is a mosaic of microtopography and different plant assemblages; these have been traditionally termed hummocks, hollows, and lawns. These microforms differ in terms of vegetation, hydrologic conditions, and soil properties; hence, the emission rates also vary considerably among these features [e.g., Bubier et al., 2003]. Consideration of the microtopography is particularly important when using chambers to estimate efflux rates. Failure to consider the spatial heterogeneity in the peatland will inevitably result in biased estimates when point measures are extrapolated to a unit area basis. Accordingly, detailed assessment of the surface topography is needed when integrating results from chamber measurements to the site scale. In contrast to chambers, eddy covariance measurements functionally integrate flux rates over the tower fetch area, thereby effectively integrating fluxes among surface microtopographic positions. The problem with the eddy covariance measurements is that it does not distinguish among the different flux sources, but gives the total ecosystem flux. Accordingly, other methods (e.g., chamber measurements) must be used to derive the soil fluxes from heterotrophic processes, from the total ecosystem flux. 
The flux of carbon and dissolved gases in the moving groundwater is seldom accounted for when estimating the $\mathrm{C}$ balance of a peatland, and it is a major uncertainty that should be addressed. For example, Nilsson et al. [2008] showed that $15-20 \mathrm{~g} \mathrm{C} \mathrm{m}^{2}$ is lost from the peatland annually in the outflow waters. Unfortunately, there are few recent or current study sites that have the capabilities for estimating gaseous and hydrologic fluxes in peatlands. Watershed-scale experimental sites, where the atmospheric and hydrologic fluxes can be considered simultaneously, are needed to provide estimates of the hydrologic fluxes.

There are also issues with the seasonality of GHG measurements. Most of the reported literature focuses on sampling during the "growing season" or snow-free period, suggesting that this is the period of major fluxes. However, recent chamber [e.g., Mäkiranta et al., 2007] and eddy covariance [e.g., Lohila et al., 2007] measurements demonstrate the importance of winter fluxes, even through the snowpack. Accordingly, sampling regimes that address the full seasonal cycle are needed, especially in light of predicted changes in climatic conditions.

\section{CLIMATIC IMPACTS OF THE LAND USE CHANGE IN PEATLANDS}

The climatic impacts of land use change can be described by radiative forcing, a term that indicates the effect that greenhouse gas emissions or sequestration have on the Earth's radiative balance. The global warming potential (GWP) of a $\mathrm{CH}_{4}$ molecule is approximately 24 times greater than that of $\mathrm{CO}_{2}$, but since $\mathrm{CH}_{4}$ decomposes faster in the atmosphere (circa 12 years), the effect is shorter, while that of $\mathrm{CO}_{2}$ continues much longer. The changes in the Earth's radiative balance leads to alterations in the surface temperatures.

Generally, pristine peatlands are a net sink of $\mathrm{CO}_{2}$ and a source of $\mathrm{CH}_{4}$ [Frolking et al., 2006]. Over the course of thousands of years of mire development, the net radiative forcing has been for a cooling climatic effect, even considering the higher GWP of $\mathrm{CH}_{4}$ emissions [Frolking and Roulet, 2007]. However, conversion to agricultural or forestry use changes the net radiative forcing independently of the natural history of the peatland. Impacts on the radiative forcing as a result of land use change are conveyed through alterations in the $\mathrm{C}$ and $\mathrm{N}$ cycles. The change may be a warming or a cooling effect depending on the altered gas emissions and the time horizon under consideration. The net radiative forcing from a managed peatland is strongly influenced by the difference between $\mathrm{CO}_{2}$ sequestration, as a result of managing plant productivity, and releases of $\mathrm{CO}_{2}$ and $\mathrm{CH}_{4}$ from the soil, which are largely regulated by alterations to soil drainage and tillage practices.

\subsection{Agriculture}

Besides releasing large amounts of $\mathrm{CO}_{2}$, drained organic soils can also contribute to the atmospheric $\mathrm{N}_{2} \mathrm{O}$ load [e.g., Kasimir-Klemedtsson et al., 1997; Flessa et al., 1998; Maljanen et al., 2003b]. Decomposition of the N-containing compounds in organic matter, linked to denitrification processes, is the primary source of the $\mathrm{N}_{2} \mathrm{O}$ with fertilizer being a minor contributing factor [Regina et al., 2004]. Despite a decrease in $\mathrm{CH}_{4}$ emissions, combined with large areas, these make organic soil croplands an important land use, which increases radiative forcing. In Finland, for instance, agricultural use is responsible for some 4-6 $\mathrm{Tg} \mathrm{CO}_{2}$ eq reported for the United Nations Framework Convention for Climate Change (UNFCCC), 25\% of the reported peat-based emissions [Lapveteläinen et al., 2007].

\subsection{Forestry}

The decrease or total cessation of $\mathrm{CH}_{4}$ emissions, following forestry drainage, causes negative radiative forcing, which means cooling, compared to the undrained conditions. If $\mathrm{C}$ sequestration increases as a whole, because of greater increases in tree stand and litter C stocks over soil C losses, the change in radiative forcing is, again, negative.

However, when climate impact is estimated, changes in non-carbon gases must also be accounted for. Drainage for forestry has been shown to increase $\mathrm{N}_{2} \mathrm{O}$ emissions significantly only at nutrient-rich peatland sites [Martikainen et al., 1993], where the $\mathrm{pH}$ is high enough for nitrification. At those sites, however, $\mathrm{N}_{2} \mathrm{O}$ emissions may become large enough to exceed the impacts of $\mathrm{CH}_{4}$ and $\mathrm{CO}_{2}$ [Klemedtsson et al., 2005], turning such sites to net greenhouse gas sources soon after drainage.

The development of a forest canopy on a previously open or sparsely treed mire causes the albedo of the site to decrease. A decreasing albedo causes a warming impact on climate, since less radiation is reflected back to the sky. Quantitative estimates of the impacts of forestry drainage on albedo and climatic warming do not exist, however.

Greenhouse gas emissions and especially radiative forcing impacts are dynamic phenomena. The aforementioned predictions are valid as long as the first post-drainage tree stand is growing and binding $\mathrm{C}$. After fellings, $\mathrm{C}$ starts to liberate back to the atmosphere, first from decomposing slash, then from biomass burning and finally from the wood products. Even if a new tree stand is established subsequently on the same site, it cannot decrease the atmospheric C pool more than the first generation did (unless the production capacity of the site for some reason increases). If the soil acts as a $\mathrm{C}$ sink or $\mathrm{C}$ neutral, the cooling impact of drainage will prevail. 
However, if a permanent $\mathrm{C}$ loss from soil is created, the climatic impact will eventually be warming.

\subsection{Peat in Energy Production}

Some $90 \%$ of the climate impact of energy production using peat fuel comes from the combustion process: 100-108 $\mathrm{g} \mathrm{CO}_{2}$ per MJ. However, a life cycle analysis of the climate impact considers also the other emission sources, such as emissions from the initial stage of the fuel peat production, those during the production phase, and potential sequestration of $\mathrm{CO}_{2}$ during after-use of the abandoned production area, the cutaway [Kirkinen et al., 2007].

Holmgren et al. [2008] have recently summarized results from life cycle analyses with comparisons to fossil fuels, such as coal and natural gas. The climate impact, expressed as modeled radiative forcing appears to be highly dependent on the emissions of the site prior to start of the production phase. Clearly, sites with high greenhouse gas emissions during the initial phase give much lower radiative forcing values for the production chain, as the high initial emissions are avoided with the start of the production [Kirkinen et al., 2007; Holmgren et al., 2008].

These analyses clearly direct peat fuel production to sites where anthropogenic impacts on the peatland carbon exchange are most drastic, namely, peatlands under agriculture and forestry. In many cases, these production chains lead to lower radiative forcings than coal over a 100-year time span and often lower than natural gas over a 150-year time span [Holmgren et al., 2008]. The problem in the interpretation of life cycle analyses is the choice of appropriate time spans.

\section{SUMMARY AND PERSPECTIVES}

Northern peatlands are a terrestrial resource of global importance, providing necessary ecological functions and valued goods and services to many communities and economies. Many of the ecosystem services provided by peatlands are derived either directly or indirectly from the soil $\mathrm{C}$ accumulation processes. The $\mathrm{C}$-sink function of a peatland involves intricate interactions among plant communities, hydrology, soils, climate, and biogeochemical processes, which yield, over time, a positive accumulation of organic matter. As a result, peatlands have the largest carbon pools (typically $>100 \mathrm{~kg} \mathrm{C} \mathrm{m}^{2}$ ) among terrestrial ecosystem types. Carbon accumulation in peatlands is regulated by the hydrologic regime, the factor that is almost always altered as a result of land use change.

Agriculture, forestry, and peat harvesting (e.g., energy and horticultural products) are the principal human-induced activities that alter the peatland. As a prerequisite to those uses, the peatland is usually drained, with the drainage being most intense under agriculture and peat harvesting. Forestry drainage is not as intensive because of the longer rotations and the adaptability of the forest overstory and understory species. Soil organic matter decomposition is stimulated following drainage, resulting in peat oxidation, typically reported as increased $\mathrm{CO}_{2}$ emissions and peat subsidence. The vegetation also changes following drainage, regardless of cropping or harvesting practices, and this change influences the net ecosystem $\mathrm{C}$ exchange rate. Where net sequestration has been enhanced, there is growing evidence that some managed peatlands may continue to function as a net $\mathrm{C}$ sink, despite the presence of drainage and active management. Peatland drainage also tends to reduce $\mathrm{CH}_{4}$ emissions, as a result of a greater aerated surface soil volume. Accordingly, active management of peatlands results in changes in the above- and belowground $\mathrm{C}$ pools and fluxes. The net effect of active management of northern peatlands has been to reduce the soil C pool because agricultural use is dominant.

There are considerable uncertainties in estimating the peatland $\mathrm{C}$ pools, fluxes, and responses to management. The issues span inadequate inventory procedures to sampling complex settings. Fundamentally, assessing changes in the soil $\mathrm{C}$ pool in peatlands is difficult because the pool size is large, and the annual changes are usually small. Accordingly, the reporting objective must be clearly stated at the onset in order to devise the most appropriate assessment. Among our recommendations are the improved precision in peat pool assessments and consideration of spatial variability when using chambers. Another critical need is sites that are monitored over long periods; it will be the long-term observatories that provide the basis for confirming our understanding of the effects of management practices on $\mathrm{C}$ dynamics and ecosystem functions of peatlands. This information is also needed as a basis for predicting how managed and natural peatlands will respond to climate change.

\section{REFERENCES}

Alm, J., et al. (2007), Emission factors and their uncertainty for the exchange of $\mathrm{CO}_{2}, \mathrm{CH}_{4}$ and $\mathrm{N}_{2} \mathrm{O}$ in Finnish managed peatlands, Boreal Environ. Res., 12, 191-209.

Bridgham, S. D., J. P. Megonigal, J. K. Keller, N. B. Bliss, and C. Trettin (2006), The carbon balance of North American wetlands, Wetlands, 26(4), 889-916.

Bubier, J. L., G. Bhatia, T. R. Moore, N. T. Roulet, and P. M. Lafleur (2003), Spatial and temporal variability in growing-season net ecosystem carbon dioxide exchange at a large peatland in Ontario, Canada, Ecosystems, 6, 353-367, doi:10.1007/s10021003-0125-0. 
Byrne, K. A., and E. P. Farrell (2005), The effect of afforestation on soil carbon dioxide emissions in blanket peatland in Ireland, Forestry, 78, 217-227.

Flessa, H., U. Wild, M. Klemisch, and J. Pfadenhauer (1998), Nitrous oxide and methane fluxes from organic soils under agriculture, Eur. J. Soil Sci., 49, 327-335.

Frolking, S., and N. T. Roulet (2007), Holocene radiative forcing impact of northern peatland carbon accumulation and methane emissions, Global Change Biol., 13, 1079-1088.

Frolking, S., N. Roulet, and J. Fuglestvedt (2006), How northern peatlands influence the Earth's radiative budget: Sustained methane emission versus sustained carbon sequestration, J. Geophys. Res., 111, G01008, doi:10.1029/2005JG000091.

Hargreaves, K. J., R. Milne, and M. G. R. Cannell (2003), Carbon balance of afforested peatland in Scotland, Forestry, 76, 299-317.

Holmgren, K., J. Kirkinen, and I. Savolainen (2008), Climate impact of peat fuel utilisation, in Peatlands and Climate Change, edited by M. Strack, pp. 70-97, Int. Peat Soc., Jyväskylä, Finland.

Kasimir-Klemedtsson, Å., L. Klemedtsson, K. Berglund, P. J. Martikainen, J. Silvola, and O. Oenema (1997), Greenhouse gas emissions from farmed organic soils: A review, Soil Use Manage., 13, 245-250.

Kirkinen, J., K. Minkkinen, T. Penttilä, S. Kojola, R. Sievänen, J. Alm, S. Saarnio, N. Silvan, J. Laine, and I. Savolainen (2007), Greenhouse impact due to different peat fuel utilisation chains in Finland-A life-cycle approach, Boreal Environ. Res., 12, 211-223.

Klemedtsson, L., K. von Arnold, P. Weslien, and P. Gundersen (2005), Soil CN ratio as a scalar parameter to predict nitrous oxide emissions, Global Change Biol., 11, 1142-1147.

Laiho, R., and J. Laine (1997), Tree stand biomass and carbon content in an age sequence of drained pine mires in southern Finland, For. Ecol. Manage., 93, 161-169.

Laiho, R., and T. Penttilä (2006), Root system carbon pools in northern peatland forests: Effects of stand density manipulations, Abstract, in Forest Ecosystem Carbon and Its Economic Implications-Seminar Presenting Results of the Research Programme "Pools and Fluxes of Carbon in Finnish Forests and Their Socio-Economic Implications,” 16.3.2006, Helsinki, Finland.

Laiho, R., H. Vasander, T. Penttilä, and J. Laine (2003), Dynamics of plant-mediated organic matter and nutrient cycling following water-level drawdown in boreal peatlands, Global Biogeochem. Cycles, 17(2), 1053, doi:10.1029/2002GB002015.

Lapveteläinen, T., K. Regina, and P. Perälä (2007), Peat based emissions in Finland's national greenhouse gas inventory, Boreal Environ. Res., 12, 225-236.

Laurila, T., et al. (2008), Ecosystem-level carbon sink measurements on forested peatlands, in Greenhouse Impacts of the Use of Peat and Peatlands in Finland Research Programme Final Report, edited by S. Sarkkola, pp. 38-40, Ministry of Agriculture and Forestry 11a/2007.

Lindroth, A., A. Grelle, and A. S. Moren (1998), Long-term measurements of boreal forest carbon balance reveal large temperature sensitivity, Global Change Biol., 4, 443-450.
Lindroth, A., L. Klemedtsson, A. Grelle, P. Weslien, and O. Langvall (2007), Measurement of net ecosystem exchange, productivity and respiration in three spruce forests in Sweden shows unexpectedly large soil carbon losses, Biogeochemistry, 89, 43-60, doi:10.1007/s10533-007-9137-8.

Lohila, A., T. Laurila, L. Aro, M. Aurela, J.-P. Tuovinen, J. Laine, P. Kolari, and K. Minkkinen (2007), Carbon dioxide exchange above a 30-year-old Scots pine plantation established on organic soil cropland, Boreal Environ. Res., 12, 141-157.

Lundin, L., and B. Bergquist (1990), Effects on water chemistry after drainage of a bog for forestry, Hydrobiologia, 196, 167-181.

Mäkiranta, P., J., et al. (2007), Soil greenhouse gas emissions from afforested organic soil croplands and cutaway peatlands, Boreal Environ. Res., 12, 159-175.

Maljanen, M., A. Liikanen, J. Silvola, and P. J. Martikainen (2003a), Methane fluxes on agricultural and forested boreal organic soils, Soil Use Manage., 19, 73-79.

Maljanen, M., A. Liikanen, J. Silvola, and P. J. Martikainen (2003b), Nitrous oxide emissions from boreal organic soil under different land-use, Soil Biol. Biochem., 35, 689-700.

Maljanen, M., V.-M. Komulainen, J. Hytönen, P. J. Martikainen, and J. Laine (2004), Carbon dioxide, nitrous oxide and methane dynamics in boreal organic agricultural soils with different soil characteristics, Soil Biol. Biochem., 36, 1801-1808.

Maljanen, M., J. Hytönen, P. Mäkiranta, J. Alm, K. Minkkinen, J. Laine, and P. J. Martikainen (2007), Greenhouse gas emissions from cultivated and abandoned organic croplands in Finland, Boreal Environ. Res., 12, 133-140.

Martikainen, P. J., H. Nykänen, P. Crill, and J. Silvola (1993), Effect of a lowered water-table on nitrous-oxide fluxes from northern peatlands, Nature, 366, 51-53.

Minkkinen, K., and J. Laine (2006), Vegetation heterogeneity and ditches create spatial variability in methane fluxes from peatlands drained for forestry, Plant Soil, 285, 289-304.

Minkkinen, K., R. Korhonen, I. Savolainen, and J. Laine (2002), Carbon balance and radiative forcing of Finnish peatlands 1900 2100 - The impact of forestry drainage, Global Change Biol., 8, 785-799.

Minkkinen, K., J. Laine, N. J. Shurpali, P. Mäkiranta, J. Alm, and T. Penttilä (2007), Heterotrophic soil respiration in forestrydrained peatlands, Boreal Environ. Res., 12, 115-126.

Minkkinen, K., K. Byrne, and C. Trettin (2008), Climate impacts of peatland forestry, in Peatlands and Climate Change, edited by M. Strack, pp. 98-122, Int. Peat Soc., Jyväskylä, Finland.

Nilsson, M., J. Sagerfors, I. Buffam, H. Laudon, T. Eriksson, A. Grelle, L. Klemedtsson, P. Weslien, and A. Lindroth (2008), Contemporary carbon accumulation in a boreal oligotrophic minerogenic mire-A significant sink after accounting for all Cfluxes, Global Change Biol., 14, 2317-2332.

Nykänen, H., J. Alm, J. Silvola, K. Tolonen, and P. J. Martikainen (1998), Methane fluxes on boreal peatlands of different fertility and the effect of long-term experimental lowering of the water table on flux rates, Global Biogeochem. Cycles, 12, 53-69.

Oleszczuk, R., K. Regina, H. Szajdak, H. Höper, and V. Maryganova (2008), Impacts of agricultural utilization of peat soils on the greenhouse gas balance, in Peatlands and Climate Change, 
edited by M. Strack, pp. 70-97, Int. Peat Soc., Jyväskylä, Finland.

Paappanen, T., A. Leinonen, and K. Hillebrand (2006), Fuel peat industry in EU-Summary report, Res. Rep. VTT-R-00545-06, VTT, Jyväskylä, Finland.

Paavilainen, E. and J. Päivänen (1995), Peatland Forestry-Ecology and Principles, 248 pp., Springer, Berlin.

Päivänen, J. (2008), Peatland forestry-The Finnish case, in After Wise Use-The Future of Peatlands, Proceedings of the 13th International Peat Congress, vol. 1, Oral Presentations, edited by C. Farrell and J. Feehan, pp. 499-501.

Reay, D. S., and D. B. Nedwell (2004), Methane oxidation in temperate soils: Effects of inorganic N, Soil Biol. Biochem., 35, 2059-2065.

Regina, K., E. Syväsalo, A. Hannukkala, and M. Esala (2004), Fluxes of $\mathrm{N}_{2} \mathrm{O}$ from farmed peat soils in Finland, Eur. J. Soil Sci., 55, 591-599.

Roulet, N. T. (2000), Peatlands, carbon storage, greenhouse gases and the Kyoto Protocol: Prospects and significance for Canada Wetlands, 20, 605-615.

Roulet, N. T., and T. R. Moore (1995), The effect of forestry drainage practices on the emission of methane from northern peatlands, Can. J. For. Res., 25, 491-499.

Rydin, H., and J. K Jeglum (2006), The Biology of Peatlands, 343 pp., Oxford Univ. Press, New York.

Sallantaus, T. (1994), Response of leaching from mire ecosystems to changing climate, in The Finnish Research Programme on Climate Change, Second Progress Report, edited by M. Kanninen, pp. 291-296, Acad. of Finland, Helsinki.

Seppälä, H., and V. Siekkinen (1993), Puun käyttö ja hiilitasapaino, Tutkimus puun käytön vaikutuksesta hiilenkiertokulkuun Suomessa 1990, Metsäntutkimuslaitoksen Tied., 473, 1-51.
Silvola, J., J. Alm, U. Ahlholm, H. Nykänen, and P. J. Martikainen (1996), $\mathrm{CO}_{2}$ fluxes from peat in boreal mires under varying temperature and moisture conditions, J. Ecol., 84, 219-228.

Statistics Finland (2009), Greenhouse gas emissions in Finland 1990-2007: National Inventory Report under the UNFCCC and the Kyoto Protocol, report, 412 pp., Helsinki. (Available at http://www.stat.fi/tup/khkinv/fi_nir_030409.pdf).

Strack, M. (Ed.) (2008), Peatlands and Climate Change, Int. Peat Soc., Jyväskylä, Finland.

Trettin, C., R. Laiho, K. Minkkinen, and J. Laine (2006), Influence of climate change factors on carbon dynamics in northern forested peatlands, Can. J. Soil Sci., 86, 269-280.

Van den Pol-van Dasselaar, A., M. L. van Beusichem, and O. Oenema (1999), Effects of nitrogen input and grazing on methane fluxes of extensively and intensively managed grasslands in the Netherlands, Biol. Fert. Soils, 29, 24-30.

von Arnold, K., P. Weslien, M. Nilsson, B. H. Svensson, and L. Klemedtsson (2005a), Fluxes of $\mathrm{CO}_{2}, \mathrm{CH}_{4}$ and $\mathrm{N}_{2} \mathrm{O}$ from drained coniferous forests on organic soils, For. Ecol. Manage., 210, 239-254.

von Arnold, K., B. Hånell, J. Stendahl, and L. Klemedtsson (2005b), Greenhouse gas fluxes from drained organic forestland in Sweden, Scand. J. For. Res., 20, 400-411.

J. Laine, Finnish Forest Research Institute, Kaironiementie 54, FI-39700 Parkano, Finland. (jukka.laine@metla.fi)

K. Minkkinen, Department of Forest Ecology, University of Helsinki, Latokartanonkaari, FI-00014 Helsinki, Finland.

C. Trettin, Center for Forested Wetlands Research, U.S. Forest Service, 3734 Highway 402, Cordesville, SC 29434, USA 